\title{
PENGARUH PENERAPAN METODE KARYA WISATA TERHADAP HASIL BELAJAR IPS MATERI JENIS-JENIS PEKERJAAN KELAS IV SDK ONA TAHUN AJARAN 2021/2022
}

\author{
Desi Maria El Puang ${ }^{1}$, Floyani Suprianti Weka² \\ 1,2PGSD FKIP UNIVERSITAS NUSA NIPA \\ 1elpuangdesimaria@gmail.com
}

\begin{abstract}
Social Science learning outcomes achieved by students of grade IV SDK Ona arerelativelylow. This is influenced by the use of methods that do not vary from teachers where grade IVteachers are moredominant in using lecture methodswithout thehelp of other methods.In learning like thisstudents become passiveand the classroom atmosphere becomes not conducive. The result of this situation is many students who obtained grades under the KKM set by the school. There are 6 out of 15 students who have reached KKM (40\%) and 9 students (60\%) who have not reached KKM. The purpose of this research was to find out the effect of the application of field trip methods on Social Sciences learning outcomes of types of work on students of grade IV SDK Ona.The research method used experimental method, pre-experemintal (non design) type One-Group Pretest-Posttest Design. The data collection techniques in this study use tests, observations and documentation. The data analysis technique used $t$ test that is to find out the effect of the application of field trip methods on Social Sciences learning outcomes of types of work on students of grade IV SDK Ona. The results showed that the average postest student score was 76.29 where this result increased after the application of the field trip method compared to the average pretest score of 61.14. The results of this study showed that there was an influence on the application of field trip methods to the results of Social Sciences learning of types of work with $t$ count $>t$ table with the acquisition is 8,739 > 1,753 . Thus it can be concluded that there is an influence on the application of field trip methods on Social Sciences learning outcomes of types of work on students of grade IV SDK Ona.
\end{abstract}

Keywords: Field trip methods, learning outcomes, Social Sciences

\begin{abstract}
ABSTRAK
Hasil belajar IPS yang dicapai siswa kelas IV SDK Ona tergolong rendah. Hal ini dipengaruhi oleh penggunaan metode yang tidak bervariasi dari guru dimana guru kelas IV lebih dominan menggunakan metode ceramah tanpa ada bantuan metode lain. Pada pembelajaran seperti ini siswa menjadi pasif dan suasana kelas menjadi tidak kondusif. Hasil dari keadaan ini mengakibatkan masih banyak siswa yang memperoleh nilai di bawah KKM yang ditetapkan oleh sekolah. Dari 15 siswa terdapat 6 siswa saja yang mencapai KKM (40\%) dan 9 siswa (60\%) yang belum
\end{abstract}


mencapai KKM. Tujuan dilakukan penelitian ini untuk mengetahui pengaruh penerapan metode karya wisata terhadap hasil belajar IPS materi jenis-jenis pekerjaan pada siswa kelas IV SDK Ona. Metode penelitian yang digunakan adalah metode eksperimen pre-eksperimental (Nondesigns) tipe One-Group Pretest-Posttest Design. Teknik pengumpulan data dalam penelitian ini menggunakan tes, observasi dan dokumentasi. Teknik analisis data yang digunakan adalah uji-t yaitu untuk mengetahui pengaruh penerapan metode karya wisata terhadap hasil belajar IPS materi jenis-jenis pekerjaan pada siswa kelas IV SDK Ona. Hasil penelitian menunjukkan bahwa rata-rata nilai posttest adalah 76,29 dimana hasil ini meningkat setelah penerapan metode karya wisata dibandingkan dengan rata-rata nilai pretest 61,14. Hasil penelitian ini menunjukkan terdapat pengaruh penerapan metode karya wisata terhadap hasil belajar IPS materi jenis-jenis pekerjaan dengan thitung $>$ ttabel dengan perolehan $8,739>1,753$. Dengan demikian dapat disimpulkan bahwa terdapat pengaruh penerapan metode karya wisata terhadap hasil belajar IPS materi jenis-jenis pekerjaan pada siswa kelas IV SDK Ona.

Kata Kunci: Metode karya wisata, hasil belajar, IImu Pengetahuan Sosial

\section{A. Pendahuluan}

Pembelajaran pada hakikatnya adalah proses interaksi antara siswa dan sumber belajar sehingga terjadi perubahan tingkah laku yang lebih baik. Untuk menentukan kualitas pembelajaran dan mencapai tujuan pembelajaran maka diperlukan penggunaan pendekatan dan model serta pemilihan model dan media pembelajaran yang sesuai dengan kompetensi yang akan dicapai. Guru hendaknya menciptakan pembelajaran yang aktif, menyenangkan dan menarik serta tidak berpusat pada guru melainkan lebih memberikan kesempatan siswa untuk lebih berperan aktif dalam kegiatan pembelajaran karena dalam kegiatan pembelajaran guru tidak hanya sebatas menyampaikan informasi, akan tetapi harus memahami bakat, minat, kemampuan, dan potensi-potensi yang dimiliki oleh siswa.

Pembelajaran IImu Pengetahuan Sosial (IPS) merupakan salah satu mata pelajaran di SD yang dapat membantu siswa untuk mengembangkan potensi siswa agar dapat peka dengan masalah sosial yang terjadi di masyarakat, memiliki sikap mental positif terhadap perbaikan segala ketimpangan yang terjadi, dan terampil mengatasi masalah yang dihadapi dalam kehidupan sehari-hari. 
Proses pembelajaran IPS pada jenjang sekolah dasar masih perlu dilakukan pembenahan. Hal ini dikarenakan masih banyaknya guru dalam pembelajaran masih menggunakan pendekatan, metode ataupun model pembelajaran yang masih sangat terbatas. Oleh sebab itu, diharapkan para guru hendaknya selalu berupaya untuk mewujudkan proses pembelajaran IPS yang aktif, inovatif, kreatif dan menyenangkan sesuai dengan ciri-ciri pembaharuan pembelajaran IPS yaitu berorientasi pada pembelajaran kontekstual (Susanto, 2014:2).

Setelah melakukan observasi di kelas IV peneliti menemukan dalam proses pembelajaran hasil belajar IPS yang dicapai siswa yang tergolong rendah dipengaruhi oleh kurang bervariasinya penerapan metode pembelajaran oleh guru dimana guru lebih dominan menggunakan metode ceramah tanpa ada bantuan metode lain yang dapat menguatkan materi yang disampaikan. Akibatnya partisipasi, dan hasil belajar siswa menjadi rendah. Pada pembelajaran seperti ini siswa menjadi pasif dan suasana kelas menjadi tidak kondusif karena siswa yang pasif sering kali tidak memperhatikan ketika guru menyampaikan materi dalam proses belajar mengajar. Dampak dari keadaan ini berpengaruh terhadap hasil belajar siswa dimana dari 15 siswa hanya 6 siswa yang mencapai Kriteria Ketuntasan Minimal (KKM) dengan persentase nilai rata-rata $40 \%$ dan 9 siswa atau sekitar $60 \%$ yang belum mencapai KKM.

Berdasarkan masalah ini, salah satu upaya meningkatkan kualitas pembelajaran adalah dengan menerapkan metode karya wisata. Metode karya wisata menurut Gunansyah dan Saputra (2014:2) adalah cara penyajian dengan membawa siswa mempelajari materi pelajaran di luar kelas. Metode ini menyajikan keadaan nyata di sekitar siswa sehingga siswa mendapatkan pengalaman secara langsung bukan hanya sebatas pengetahuan verbal berdasarkan informasi saja (Kartawidjaja dalam Dartini, 2017:44). Dengan metode karya wisata juga membantu guru agar tidak terlalu banyak menjelaskan materi karena siswa dapat belajar secara langsung dengan cara mengamati atau melihat secara langsung. Oleh sebab itu, dengan adanya penggunaan metode diharapkan dapat meningkatkan hasil 
belajar siswa, khusus mata pelajaran IPS materi jenis-jenis pekejaan.

Hal ini didukung oleh penelitian yang telah dilakukan oleh Oktaviana, Wurdjinem dan Tarmizi (2018) dengan judul "Pengaruh Metode Karyawisata terhadap Hasil Belajar Siswa pada Mata Pelajaran IPS". Hasil penelitian menunjukkan, bahwa terdapat pengaruh yang signifikan penggunaan metode karyawisata terhadap hasil belajar siswa pada mata pelajaran IPS. Hal ini dibuktikan dengan hasil perhitungan uji hipotesis dimana $t_{\text {hitung }}$ 2,315 lebih besar dari tabel yaitu 2,00 pada taraf signifikan $5 \%$. Sehingga Ho ditolak dan Ha diterima.

Berdasarkan masalah dan adanya kajian terdahulu terkait penggunaan metode karya wisata, maka peneliti tertarik untuk melakukan penelitian pada siswa kelas IV tentang "Pengaruh Penerapan Metode Karya Wisata terhadap Hasil Belajar IPS Materi Jenis-Jenis Pekerjaan Pada Siswa Kelas IV SDK Ona Tahun Ajaran 2021/2022".

Tujuan dilakukan penelitian ini adalah untuk mengetahui pengaruh penerapan metode karya wisata terhadap hasil belajar IPS materi jenis-jenis pekerjaan kelas IV SDK Ona. Penelitian ini dapat memberikan manfaat secara teoretis dan praktis. Secara teoretis dapat memberikan sumbangan teori berupa ilmu pengetahuan serta masukan bagi dunia pendidikan dan pengajar, khususnya dalam penerapan metode karya wisata pada mata pelajaran IPS materi jenis-jenis pekerjaan. Secara praktis dapat memberikan manfaat bagi dimana dapat memperbaiki proses pembelajaran IPS sehingga aktivitas dan hasil belajar siswa meningkat. Bagi guru, dapat memilih metode pembelajaran IPS yang sesuai dengan materi yang akan diajarkan. Bagi siswa, dapat memahami lebih mendalam tentang pembelajaran IPS secara langsung dan lebih aktif dalam proses pembelajaran dan meningkatkan prestasi belajarnya. Bagi peneliti lanjutan, dapat menambah wawasan mengenai metode karya wisata sehingga dapat dijadikan bahan referensi untuk penelitian selanjutnya yang sejenis dalam melakukan penelitian di sekolah-sekolah.

\section{B. Metode Penelitian}

Metode penelitian yang digunakan yaitu kuantitatif dimana menggunakan data berupa angka 
dan analisisnya menggunakan teknikteknik statistika. Jenis penelitian ini adalah eksperimen dimana meneliti hubungan sebab akibat dengan manipulasi atau diberi perlakuan (dirancang dan dilaksanakan) oleh peneliti. Sugiyono (2015:107) menjelaskan bahwa metode penelitian eksperimen adalah metode yang digunakan untuk mencari pengaruh perlakuan tertentu terhadap yang lain dengan kondisi yang dikendalikan.

Desain penelitian yang digunakan adalah One-Group Pretest-Posttest dimana terdapat pretest, sebelum diberi perlakuan dan dilanjtkan dengan postest. Dengan demikian hasil perlakuan dapat lebih akurat, karena dapat dibandingkan dengan keadaan sebelum diberi perlakuan dan setelah diiberikan tereatmen (perlakuan) dengan menggunakan metode karya wisata (Sugiyono, 2015:110-111).

Penelitian ini dilaksanakan di SDK Ona Nangahure, Kecamatan Alok Barat, Kabupaten Sikka. Menurut Azwar (2011:25) populasi adalah kelompok subjek yang hendak dikenai generalisasi hasil penelitian dimana memiliki ciri atau karakteristik bersama yang membedakannya dari kelompok subjek lainnya. Dalam penelitian ini populasi yang diambil oleh peneliti adalah siswa kelas IV SD Katolik Ona Tahun Ajaran 2020/2021, dengan jumlah 15 siswa. Menurut Sugiyono (2012:118) sampel adalah sebagian dari jumlah dan karakteristik yang dimiliki oleh populasi. Jadi sampel dalam penelitian ini adalah siswa kelas IV SDK Ona yang berjumlah 15 orang.

Teknik pengumpulan data yang digunakan dalam penelitian ini adalah tes, observasi dan dokumentasi dengan instrumen soal tes dan lembar observasi. Teknik analisis data menggunakan uji untuk mengetahui ada tidaknya pengaruh metode karya wisata terhadap hasil belajar siswa. Kriteria dalam uji-t pada taraf signifikan $\alpha=0,05$ dan dengan derajat kebebasan /dk ( $\mathrm{n} 1+$ $\mathrm{n} 2-2$ ) adalah jika $t_{\text {hitung }}>t_{\text {tabel }}$ maka hipotesis alternatif $(\mathrm{Ha})$ diterima dan hipotesis nihil (Ho) ditolak. Sebaliknya jika $t_{\text {hitung }}<t_{\text {tabel }}$ maka hipotesis nihil (Ho) diterima dan hipotesis alternatif $(\mathrm{Ha})$ ditolak.

\section{Hasil Penelitian dan Pembahasan}

\section{Hasil Penelitian}

Untuk mengetahui hasil belajar siswa, peneliti memberikan tes 
tertulis berupa pretest dan postest sebanyak 10 soal yang sebelumnya telah diuji kevalidan instrumennya.

\section{Uji Normalkitas}

Uji normalitas digunakan untuk mengetahui distribusi penyebaran data setiap variabel dalam penelitian. Uji normalitas bertujuan untuk mengetahui sebaran dari skor masing-masing variabel apakah data yang bersangkutan berdistribusi normal atau tidak. Untuk melakukan uji normalitas digunakan uji liliefors (Lo) yang dihitung dengan menggunakan SPSS 21. Dari hasil perhitungan tersebut diperoleh hasil sebagai berikut.

Tabel 1 Hasil Uji Liliefors terhadap Nilai Pretest dan Posttest Siswa

\begin{tabular}{|c|c|c|}
\hline & \multicolumn{2}{|c|}{ Kolmogorov-Smirr } \\
\hline & Statistic & Df \\
\hline Pretest & .149 & \\
\hline Posttest & .219 & \\
\hline
\end{tabular}
dengan SPPS 21, uji normalitas dengan uji liliefors diketahui apabila Lo $<\mathrm{L}_{\text {tabel }}$ maka populasi berdistribusi normal sedangkan apabila Lo > Ltabel ,maka populasi distribusi tidak normal dengan nilai signifikan 0,05 atau $5 \%$ $=0,220$ dengan $\mathrm{N}=15$. Pada tabel 1 diketahui bahwa untuk data pretest hasilnya menunjukkan bahwa Lo

$$
(0,200)<L_{\text {tabel }}(0,220) \text { berarti }
$$
populasi berdistribusi normal. Sedangkan posttest diketahui Lo $(0,200)=L_{\text {tabel }}(0,220)$ berarti populasi berdistribusi normal. Hal ini berarti bahwa data yang diperoleh pada ests of Normality

nov $^{a}$

\begin{tabular}{|c|c|c|c|c|}
\hline & Sig. & Statistic & $\mathrm{df}$ & Sig. \\
\hline 15 & $.200^{*}$ & .930 & 15 & 270 \\
\hline 15 & $200^{*}$ & .946 & 15 & .464 \\
\hline
\end{tabular}

yang berdistribusi normal dan propesional sehingga data tersebut berdistribusi normal dan pengolahan terhadap data tersebut dapat dilanjutkan ketahap berikutnya yaitu pengujian Hipotesis.

\section{Uji Hipotesis}

Setelah melakukan uji normalitas, maka langkah selanjutnya adalah melakukan pengujian hipotesis. Pengujian hipotesis dilakukan untuk mengetahui apakah ada pengaruh penerapan metode karya wisata terhadap hasil belajar IPS materi jenis-jenis pekerjaan pada siswa kelas IV SDK Ona. Karena kedua data berdistribusi normal maka uji statistik yang digunakan adalah uji 
t untuk memperoleh t hitung. Hasil uji

hipotesis penelitian ini dapat dilihat

pada tabel 2 berikut.

Tabel 2. Hasil Analisis Data Uji Hipotesis Variabel Metode Karya Wisata dan Hasil Belajar

Dari hasil perhitungan didapat

Hasil penelitian menunjukkan

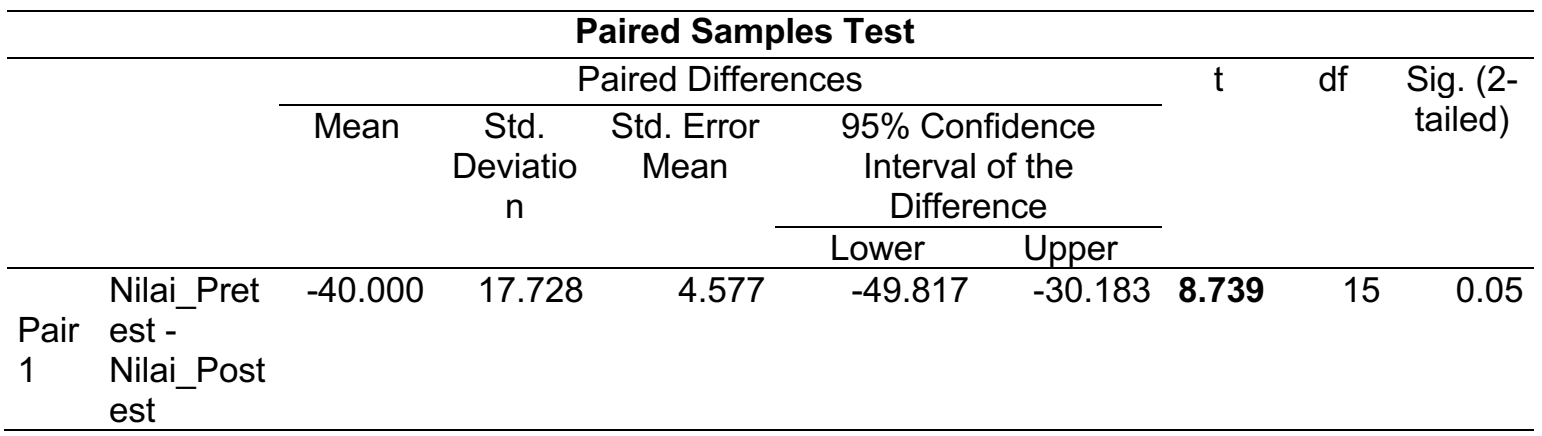

harga t hitung sebesar 8,739 serta $t$ tabel dengan $\mathrm{dk}=15$ dan taraf signifikan= 0,05 adalah 1,753.

Selanjutnya karena jika thitung > ttabel maka hipotesis alternatif $(\mathrm{Ha})$ diterima dan hipotesis nihil (Ho) ditolak. Jika thitung < ttabel maka hipotesis nihil (Ho) diterima dan hipotesis alternatif $(\mathrm{Ha})$ ditolak. Oleh karena itu, berdasarkan hasil ini dapat disimpulkan bahwa thitung > ttabel $(8,739>1,753)$ sehingga disimpulkan $\mathrm{Ho}$ ditolak dan $\mathrm{Ha}$ diterima, yaitu terdapat pengaruh penerapan metode karya wisata terhadap hasil belajar IPS materi jenis-jenis pekerjaan pada siswa kelas IV SDK Ona Tahun Ajaran 2021/2022.

\section{Pembahasan}

bahwa pengaruh penerapan metode karya wisata berpengaruh dalam meningkatkan hasil belajar IPS materi jenis-jenis pekerjaan kelas IV. Pengaruh tersebut dapat dilihat pada hasil nilai pretest maupun posttest siswa. Pretest dilaksanakan sebelum diberi tindakan dan posttest yang dilakukan setelah diberi perlakuan atau tindakan menggunakan metode karya wisata.

Penggunaan metode dalam pembelajaran sangatlah penting karena metode merupakan bagian dari suatu strategi pembelajaran untuk mencapai tujuan pembelajaran. Seperti yang dikemukakan Syamsidah (2007:1), metode merupakan cara menyampaikan atau mentransfer ilmu yang tepat sesuai dengan anak sehingga menghasilkan 
pemahaman yang maksimal bagi anak didik. Metode merupakan bagian dari strategi pembelajaran untuk mencapai tujuan pembelajaran. Ahmadi dan Prastya (dalam Nasution, 2010:13) mengemukakan bahwa adanya metode pembelajaran yang tepat pada dasarnya bertujuan untuk menciptakan kondisi pembelajaran sehingga siswa dapat belajar secara aktif dan menyenangkan berdampak positif dalam belajar dan prestasi yang optimal. Oleh karena itu, setiap pembelajaran harus menggunakan metode yang sesuai dengan tujuan pembelajaran agar berdampak pada keberhasilan pembelajaran siswa.

Penggunaan metode ini dapat membantu siswa dalam mengatasi rendahnya hasil belajar IPS materi jenis-jenis pekerjaan. Metode pembelajaran memiliki karakteristik berbeda-beda dalam membentuk pengalaman belajar siswa, namun satu dan yang lainnya saling menunjang. Terdapat dua macam pembelajaran yaitu pembelajaran di dalam kelas (indoor) dan pembelajaran di luar kelas. Pembelajaran di luar kelas (outdoor) identik dengan pembelajaran karyawisata (fieldtrip) artinya aktivitas belajar siswa berada di luar kelas. Gunarti, dkk.

(2018:8.3) mengemukakan bahwa metode karya wisata adalah suatu metode dalam kegiatan pembelajaran dengan cara mengamati sesuai kenyataan yang ada secara langsung, meliputi manusia, hewan, tumbuh-tumbuhan, dan benda-benda lainnya. Melalui pengamatan secara langsung anak memperoleh kesan yang sesuai dengan pengamatannya. Pengamatan diperoleh melalui panca indra, yaitu penglihatan (mata), pendengaran (telinga), pengecapan (lidah), pembauan (hidung), dan perabaan (kulit).

\begin{tabular}{llr}
\multicolumn{1}{c}{ Selain } & \multicolumn{1}{c}{ itu } & metode \\
pembelajaran & karya & wisata \\
merupakan salah satu & metode \\
pembelajaran & yang relevan dan \\
realistis, & dimana & metode
\end{tabular}
pembelajaran ini dapat memberikan dampak positif terhadap siswa seperti membangkitkan rasa ingin tahu siswa, membangkitkan sikap analistis, membuat pembelajaran bersifat aktual dan faktual, membina kebiasaan belajar kelompok maupun individu. Dalam pelaksanaanya metode melibatkan siswa untuk belajar secara individu juga belajar secara kelompok dalam rangka 
mencapai hasil belajar siswa yang diharapkan. Dengan menggunakan metode karya wisata, siswa terlihat lebih antusias dalam berdiskusi kelompok, mengerjakan tugas yang diberikan guru, mencapai pemahaman lebih secara individu, saling membantu dan bekerjasama dalam kelompok serta melatih keuletan, rasa ingin tahu dan tanggung jawab. Seperti yang dikatakan Sakdiyah dan Heraris (2017) bahwa dengan metode karya wisata, pengalaman yang didapat langsung akan sangat berharga dalam pembelajaran IPS karena informasi dan materi dapat tersimpan lama dalam ingatan dan juga mampu memberikan wawasan yang lebih tepat dan akurat. Hal ini membuktikan bahwa metode karya wisata dapat memanfaatkan lingkungan nyata dan aktual sebagai bahan pelajaran yang relevan dengan kebutuhan masyarakat dan dapat merangsamg kreativitas dari siswa.

\section{Kesimpulan}

Berdasarkan hasil penelitian dan pembahasan, dapat disimpulkan bahwa terdapat pengaruh penerapan metode karya wisata terhadap hasil belajar IPS materi jenis-jenis pekerjaan kelas IV SDK Ona Tahun
Ajaran 2021/2022. Dalam penggunaan metode karya wisata guru mengajak siswa ke luar kelas atau di luar sekolah untuk mempelajari dan menyelidiki sesuatu obyek tertentu. Karya Wisata memiliki prinsip pengajaran modern yang memanfaatkan lingkungan nyata dalam pengajaran, siswa dapat berpartisipasi dalam berbagai kegiatan yang dilakukan. Setelah mempelajari dan mengamati, siswa akan diuji kemampuannya dalam memahami proses pembelajaran IPS materi jenis-jenis pekerjaan.

Pada penelitian ini dibuktikan dari data yang menunjukkan bahwa hasil rata-rata nilai pretest 61,14 sedangkan nilai rata-rata posttest 76,29 . Dengan menggunakan uji-t didapat thitung sebesar 8,739 serta nilai tabel sebesar 1,753 . Selanjutnya dikarenakan $t_{\text {hitung }}>t_{\text {tabel }}$ maka Ho: "tidak terdapat pengaruh penggunaan metode karya wisata terhadap hasil belajar IPS pada siswa kelas IV SDK Ona ditolak, dan $\mathrm{Ha}$ : "terdapat pengaruh penerapan metode karya wisata terhadap hasil belajar IPS materi jenis-jenis pekerjaan pada siswa kelas IV SDK Ona diterima.

Adapun saran yang diberikan dari hasil penelitian ini yaitu bagi 
guru, hendaknya dapat memilih metode pembelajaran yang tepat salah satunya adalah metode karya wisata, karena dengan metode karya wisata dapat meningkatkan hasil belajar IPS. Selain itu dengan penggunaan metode karya wisata guru diharapkan dapat menciptakan suasana belajar yang menyenangkan agar siswa termotivasi dan bergairah dalam belajar. Bagi siswa, hendaknya lebih aktif dalam mengikuti pembelajaran agar hasil belajar dapat meningkat. Setiap siswa hendaknya menjalani komunikasi yang baik dengan guru pada saat proses pembelajaran dan hendaknya siswa tidak bosan untuk bertanya apabila mengalami kesulitan dalam belajar. Bagi peneliti lanjutan, hendaknya dapat meneliti permasalahan ini secara lebih mendalam dengan sampel yang lebih besar serta materi yang berbeda agar dapat lebih inovatif dalam memilih metode pembelajaran yang efektif sehingga hasil belajar siswa dapat meningkat.

\section{DAFTAR PUSTAKA}

Azwar, S. (2011). Metode Penelitian. Yogyakarta: Pustaka Pelajar.

Djamarah, A. (2007). Penerapan Metode Karya Wisata Dengan Pemanfaatan Lingkungan Untuk Merangsang Kreativitas Siswa.
Surabaya. Universitas Negeri Surabaya.

Dartini, E. (2017). Penggunaan Metode Karyawisata Untuk Meningkatkan Hasil Belajar Siswa Pada Materi Kenampakan Alam Di Lingkungan Kabupaten/Kota. DWIJACENDEKIA:Jurnal Riset Pedagogik, 43-49.

Nasution. (2010). Berbagai

Pendekatan dalam Proses

Belajar dan Mengajar. Jakarta: Bumi Aksara.

Gunansyah, G. \& Saputra, H. Y. (2014). Penerapan Metode Karya Wisata Untuk Meningkatkan Motivasi Dan Hasil Belajar Pada Siswa Sekolah Dasar. Jurnal PGSD (Universitas Negeri Surabaya), 1-10.

Gunarti, dkk. (2018). Metode Perilaku

Dan Kemampuan Dasar Anak

Usia Dini. Jakarta. Universitas Terbuka.

Sakdiyah, S. H. \& Heraris, D. Z. 2017. Peningkatan Pemahaman Kenampakan Alam Dan Buatan Melalui Metode Karyawisata. Jurnal JPIG, 29-35.

Sugiyono. (2012). Metode Penelitian Kuantitatif Kualitatif dan R\&B. Bandung: Alfabeta.

Sugiyono. (2015). Metode Penelitian Kombinasi (Mix Methods). Bandung: Alfabeta

Susanto, A. (2014). Pengembangan Pembelajaran IPS di Sekolah Dasar. Jakarta: Prenadamedia Group. 
Syamsidah. (2007). Dasar Pertimbangan Memilih Strategi, Metode, Dan Teknik Dalam Pembelajaran. Makassar:Pendidikan Agama Islam Negeri.

Oktaviana, T., Wurjinem \& Tarmizi, P. (2018). Pengaruh Metode Karyawisata Terhadap Hasil Belajar Siswa Pada Mata Pelajaran IPS. Juridikdas: Jurnal Riset Pendidikan Dasar, $36-42$ 